\title{
Bathonian and Callovian (Middle Jurassic) dinoflagellate cysts and acritarchs from Franz Josef Land, Arctic Soviet
}

\section{MORTEN SMELROR}

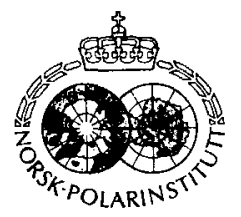

\begin{abstract}
Smelror, M. 1987: Bathonian and Callovian (Middle Jurassic) dinoflagellate cysts and acritarchs from Franz Josef Land, Arctic Soviet. Polar Research 5 n.s., 221-238.

Well preserved dinoflagellate cyst and acritarch assemblages are recorded from Upper Bathonian and Callovian deposits on Northbrook Island, Franz Josef Land. More than 45 species have been identified. Two new species are proposed: Parvocysta bjaerkei sp. nov., and Meiourogonyaulax spongiosa sp. nov. The recorded marine microfloras are compared with assemblages reported from contemporaneous strata in Svalbard.
\end{abstract}

Morten Smelror, Continental Shelf and Petroleum Technology Research Institute Ltd., P.O. Box 1883 Jarlesletta, N-7001 Trondheim, Norway; March 1987 (revised August 1987).

Franz Josef Land is a group of about 75 islands situated in the northeastern part of the Barents Sea (Fig. 1). Geologically the group bears a close relation to eastern Svalbard, whereas it is distinctly different from Novaya Zemlya. The samples included in this study are from Northbrook Island, one of the southernmost islands within the archipelago.

Jurassic and Early Cretaceous palynomorph assemblages have been recorded from Franz Josef Land by Romanovskaya (in Dibner \& Shulgina 1960) and Smelror (1986). Romanovskaya described assemblages characterized by high abundance of conifer pollen and large quantities of Bennetittalean and Ginkgophytes pollen from argillaceous rocks containing Arcticoceras sp. (Macrocephalites sp.). Only the spore-pollen composition of these Middle Jurassic deposits on Hocker Island were listed, and no marine palynomorphs were mentioned. Smelror (1986) listed 41 species of dinoflagellate cysts, acritarchs, pollen, and spores contained in six samples from Cape Flora and Windy Gully on Northbrook Island. However, this study had no stratigraphic control of the Jurassic erratic samples which the author suggested were of Callovian and possibly Lower Oxfordian age. The objectives of the present study have been to elucidate more data concerning the marine microflora (partly recovered from well-dated strata) from the Late Middle Jurassic of Franz Josef Land, and to compare the dinoflagellate cyst and acritarch assem- blages with time-equivalent assemblages recorded from the Svalbard archipelago in the western Barents Sea region.

\section{The Jurassic strata of Northbrook Island}

The Jurassic deposits are chiefly situated in the southern part of the Franz Josef Land group. A stratigraphic survey of the marine Middle and Upper Jurassic deposits in Franz Josef Land was given by Dibner \& Shulgina (1960). At Cape Flora on Northbrook Island the Middle Jurassic strata reach a maximum thickness of $157 \mathrm{~m}$. A sketch of the Cape Flora section was published already in 1900 by F. Nansen (Fig. 2). However, Dibner \& Shulgina (1960) argued that some of the fossils of the Nansen collection from Cape Flora were misidentified by Pompeckj (1900), and consequently that the proposed ages for the strata were erroneous.

On Cape Flora, Upper Aalenian and Bathonian deposits rest with small angular unconformity on continental arenaceous sediments of Lower Jurassic age (Dibner \& Shulgina 1960). The lightgrey Aalenian alearolites and aleuropelites show a visible thickness of $3 \mathrm{~m}$. Apparently resting immediately on these deposits is soft clay with nodules of sandy marls exposed at an interval 7 $10 \mathrm{~m}$ above sea level (Nansen 1900; Dibner \& Shulgina 1960). From these deposits a fossil fauna 


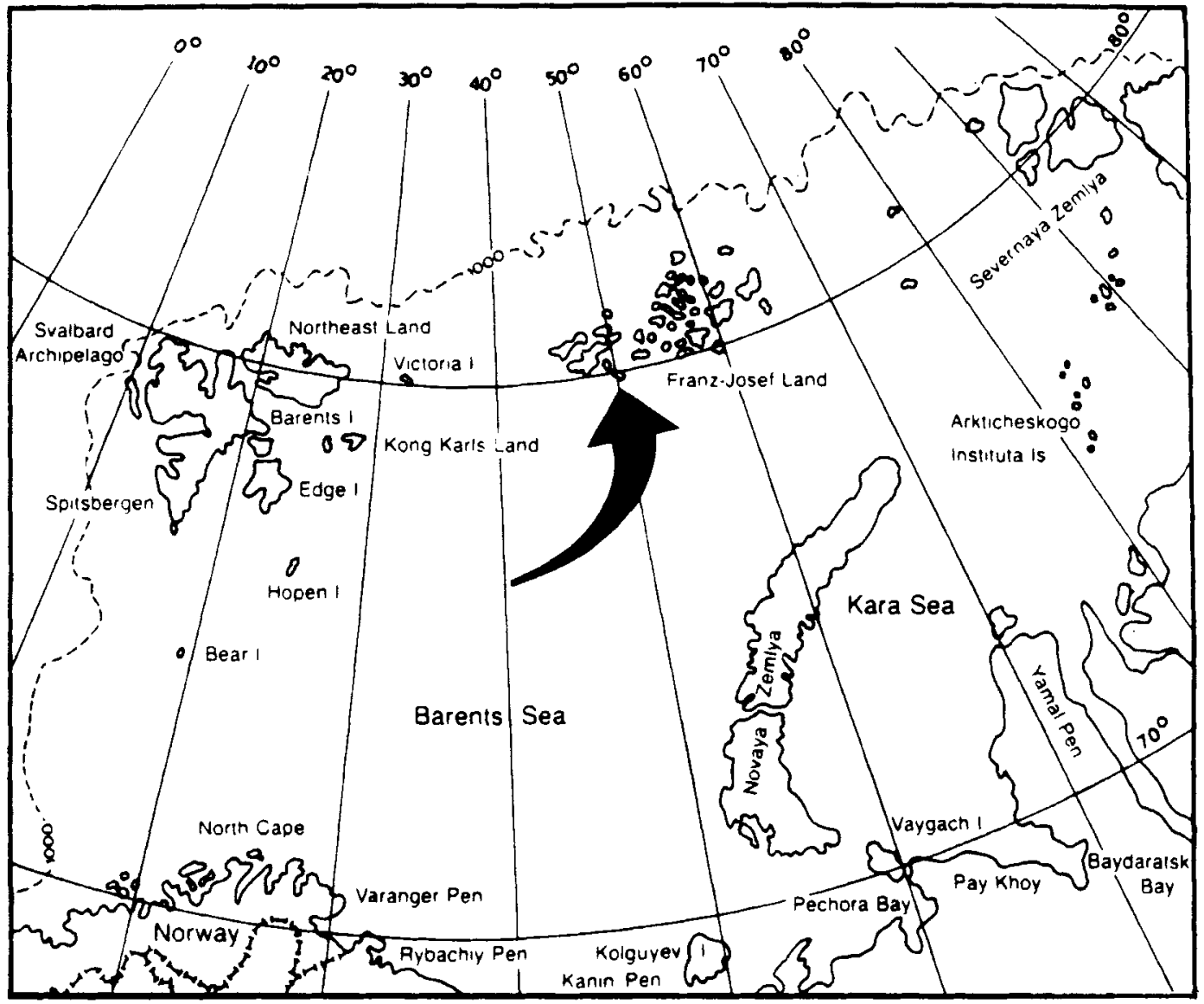

Fig. 1. Map of the Barents Sea Region. Location of Northbrook Island within the Franz Josef Land archipelago is indicated by arrow.

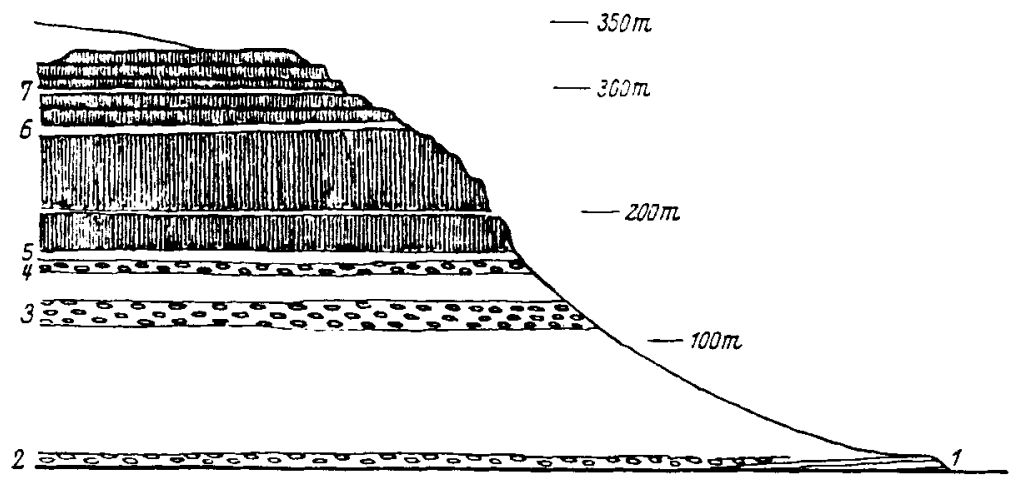

Fig. 2. Sketch of the Cape Flora section. 1. Thin alternating strata of sand with black carboniferous seams, 2. Lowermost fossiliferous horizon of soft clay with nodules of sandy marl. 3. Middle fossiliferous horizon of soft stratified clay with bands of phosphatic and calcareous nodules, 4. Upper fossiliferous horizon of soft clay, with band of nodules of clay-sandstone, 5. Horizon of soft clay. 6 and 7 . Plant-bearing beds of shale and sandstone between beds of shale and sandstone between the successive layers of basalt (from Nansen 1900). 
containing Lingula beani, Discina reflexa, Oxytoma (Pseudomonotis) jacksoni, and Hibolites (Belemnites) cf. beyrichi is recorded. Pompeckj (1900) suggested a Lower Bajocian age for this unit, but Dibner \& Shulgina (1960) argued that since these listed fossils occur together with Aalenian species, these forms should be classed as Aalenian.

From about 10 to $113 \mathrm{~m}$ the section at Cape Flora is covered by scree, but the succeeding $24 \mathrm{~m}$ consist of soft, stratified horizontal clays packed with phosphoritic concretions and calcareous nodules. The concretions contain fossil faunas consisting basically of bivalves and, to a lesser degree, ammonites and belemnites. Unidentifiable plant remains also occur. Among the fauna recorded from this unit, Pompeckj (1900) identified Macrocephalites kaettlitzi, $M$. ishamea var. arctica, $M$. pila, Cadoceras frearsi, Cadoceras sp., and Belemnites sp. According to Pompeckj, these fossils date the clays as Lower Callovian. Later these fossils were reexamined by Spath (1932), who placed the ammonites described as Macrocephalites within the Bathonian genus Arctocephalites, and also questioned the identification of the ammonites described as Cadoceras by Pompeckj (1900). According to Spath (1947), the genus Arctocephalites is characteristic of the Upper Bathonian, while Arkell (1956) regarded both Arctocephalites and Cranocephalites as Lower Callovian forms. However, the definition of Arctocephalites as distinctly Upper Bathonian seems to be widely accepted (Dibner \& Shulgina 1960; Smith et al. 1976), and the described interval from 113-137 $\mathrm{m}$ above sea level at Cape Flora is here regarded as Upper Bathonian.

The next mappable sedimentary strata are seen at a height of 150-172 $\mathrm{m}$ a.s.l., above the scree that has covered the Bathonian deposits. Here clays are exposed with numerous structures of the 'cone-in-cone' variety and intercalations of large arenaceous concretions (Nansen 1900; Dibner \& Shulgina 1960). From these beds, Pompeckj (1900) identified the bivalves Pseudomonotis cf. ornata, Pecten lindstroemi, Pecten cf. demissens, Lima cf. duplicata, Leda cf. nuda, and the ammonites Cadoceras tschefkini, Cadoceras stenolobum, Pseudocadoceras nanseni, Cylindroteuthis subextensa and Pachyteuthis panderi. This fauna was placed in the Middle Callovian by Pompeckj (1900), but V. I. Bodylyevsky (Dibner \& Shulgina 1960, p. 73) later suggested that species assignable to the genus Cadoceras, together with Pseudocadoceras nanseni, are more likely to indicate an early Upper Callovian age.

Just beneath the lowermost basalt, Nansen (1900) recognized two thin non-fossiliferous bands of black shale. A specimen of the Upper Callovian ammonite Quenstediceras lamberti was found enclosed in the basalt, and a specimen of Quenstediceras vertumnum was found in the scree close to the uppermost sedimentary layers and the basalt covering them (Nansen 1900).

According to Newton \& Teall (1897), the Jurassic strata found at Cape Gertrude, $3-4 \mathrm{~km}$ east of Cape Flora, show great similarities to those at Cape Flora, even though some more sandy beds occur (Horn 1932). Windy Gully is located between Cape Flora and Cape Gertrude, but G. Horn who collected the examined material from Windy Gully gave no descriptions of the sedimentary strata in that area.

\section{Material and methods}

The samples investigated in the present study are from Cape Flora and Windy Gully on Northbrook Island. The samples from Cape Flora were collected by Dr. F. Nansen in 1896 at the end of the Norwegian North Polar Expedition 1893-96. The samples from Windy Gully were collected by $G$. Horn during the Norwegian Expedition to Franz Josef Land in 1930. All samples were later deposited in the collections of Paleontologisk Museum, Oslo. Details of stratigraphic levels and proposed ages of the samples investigated are given in Table 1.

The samples were prepared by standard techniques (see Barss \& Williams 1973) at IKU in Trondheim. Slides with the figured specimens are kept in the collections of Paleontologisk Museum. Oslo.

\section{Dinoflagellate cyst and acritarch assemblages}

All processed samples yielded well preserved palynomorphs. In general, terrestrially derived palynomorphs are the most common, except in the samples CF-2 and CF-U from Cape Flora, where dinoflagellate cysts dominate the total microflora. The number of marine species recorded in each sample varies from between 15 and 32 , except in the uppermost sample WG-3 from 
Table 1. Stratigraphic levels and proposed ages of the investigated samples.

\begin{tabular}{|c|c|c|c|c|c|}
\hline Sample & Locality & Macrofossil assemblage & Pompeckj 1900 & $\begin{array}{c}\text { Proposed ages } \\
\text { Dibner \& Shulgina } 1960\end{array}$ & This study \\
\hline WG1 & Windy Gully. $99 \mathrm{~m}$ & & & & Upper Bathonian \\
\hline WG? & Windy Gully, $151 \mathrm{~m}$ & & & & Upper Bathonian \\
\hline WG3 & Windy Gully, $165 \mathrm{~m}$ & & & & Callovian \\
\hline \multirow[t]{2}{*}{ CF1 } & Cape Flora, $130 \mathrm{~m}$ & Arctocephalites kaetlitzi & Lower & Upper & Upper \\
\hline & & A. pilaeformis & Callovian & Bathonian & Bathonian \\
\hline $\mathrm{CF} 2$ & Cape Flora, $135 \mathrm{~m}$ & A. ellepticus & & & \\
\hline \multirow[t]{2}{*}{$\mathrm{CF} 3$} & Cape Flora. $168 \mathrm{~m}$ & Cadoceras tschefhini & Middle & Early Upper & Early Upper \\
\hline & & $\begin{array}{l}\text { Cadoceras stenolobum } \\
\text { Pseudocadoceras nanseni }\end{array}$ & Callovian & Callovian & Callovian \\
\hline $\mathrm{CFU}$ & Cape Flora, crratic & & & & $\begin{array}{l}\text { Early Upper } \\
\text { Callovian }\end{array}$ \\
\hline
\end{tabular}

Windy Gully, which yielded only three dinoflagellate cyst species and two species of acritarchs. A list of the marine microplankton taxa recorded is shown in Table 2 .

\section{Upper Bathonian assemblages}

The Upper Bathonian samples yielded moderately rich assemblages of dinoflagellate cysts and acritarchs, with 15 to 20 taxa being observed. The most common dinoflagellate cyst taxa in the two samples WG-1 and WG-2 from Windy Gully and sample CF-1 from Cape Flora are Sirmiodinium grossii (10-15\% of the total microflora). Sentusidinium spp. (5-10\%) and Escharisphaeridia spp. (5-10\%). Pluriarvalium osmingtonense and Chytroeisphaeridia chytroeides are also relatively common (approximately $5 \%$ of the total microflora), while each of the remaining species of marine organic-walled microplankton represents less than $4 \%$. In sample CF-2 from Cape Flora, Chlamydophorella sp. A and Pluriarvalium osmingtonense are most abundant (approximately 18\%), while Ctenidodinium spp. and Chytroeisphaeridia chytroeides are present in significant amounts ( 9 and $7 \%$ of the total microflora). The remaining taxa, including Sirmiodinium grossii, Escharisphaeridia spp. and Pareodinia spp. are more subordinate, each representing less than $5 \%$.

\section{Callovian assemblages}

The Callovian assemblages recorded from Cape Flora are more diverse than the assemblages registered from the Upper Bathonian strata, with 29 species observed in sample CF- 3 and 32 in erratic sample CF-U. As for the Upper Bathonian samples, terrestrial palynomorphs are the most abundant elements in the early Upper Callovian sample CF-3, while sample CF-U is characterized by a dominance of marine species. The most prominent marine taxa in sample CF-3 are $M e i$ ourogonyaulax spp. together with Lithodina spp. (12\% of the total microflora), Chlamydophorella sp. A., Nannoceratopsis pellucida, and Valensiella ovula (each representing approximately 5\%). Sample CF-U is characterized by a high abundance of Meiourogonyaulax spp. (35\%) and Sirmiodinium grossii (15\%). Chlamydophorella $\mathrm{sp.}$ $\mathrm{A}$ and Valensiella spp. represent approximately $5 \%$ each of the total microflora assemblage in sample CF-U, while the remaining recorded species are less abundant.

The uppermost sample investigated from Windy Gully, WG-3, is dominated by spores including Laevigatosporites sp., Exesipollenites tumulus, and Sphaeripollenites subgranulatus. The only recorded marine species are the dinoflagellate cysts Ellipsoidictyum cinctum, Escharisphaeridia pocockii, Valensiella ovula, the acritarchs Micrhystridium sp., and the prasinophycean algae Pterospermopsis sp., which are present in low numbers.

\section{Biostratigraphy}

Dinoflagellate cyst zonation schemes covering the Upper Bathonian-Callovian of the Canadian Arctic have been published by Johnson \& Hills (1973) and Davies (1983), offshore southeast Canada by Williams (1977), and northwest Europe by Herngreen \& de Boer (1978), Sarjeant (1979), Riley \& Fenton (1982), and Woollam \& Riding (1983). The most detailed zonation schemes are 
Table 2. List and numerical distribution of the recorded dinoflagellate cysts and acritarchs.

\begin{tabular}{|c|c|c|c|c|c|c|c|}
\hline \multirow[b]{3}{*}{ Taxon } & \multicolumn{7}{|c|}{ Samples } \\
\hline & \multicolumn{3}{|c|}{ Windy Gully } & \multicolumn{4}{|c|}{ Cape Flora } \\
\hline & WG1 & WG2 & WG3 & CF1 & CF2 & CF3 & $\mathrm{CFU}$ \\
\hline Ambonosphaera calloviana Fensome 1979 & & & & & & 2 & 3 \\
\hline Caddasphaera halosa (Filatoff) Fenton et al. 1980 & 6 & 8 & & 5 & 4 & 3 & 4 \\
\hline Cassiculosphaeridia dictydia (Sarjeant) Riley \& Fenton 1982 & 1 & 2 & & 1 & 1 & 1 & \\
\hline Chlamydophorella sp. A of Davies 1983 & & 5 & & & 35 & 9 & 11 \\
\hline Chytroeisphaeridia chytroeides (Sarjeant) Downie \& Sarjeant 1965 & 10 & 11 & & 10 & 15 & 4 & \\
\hline Ctenidodinium continuum Gocht 1970 & & & & & 6 & 2 & 2 \\
\hline Ctenidodinium ornatum (Eisenack) Deflandre 1938 & & & & & 11 & 3 & 3 \\
\hline Cymatiosphaera spp. & 2 & 3 & & 1 & & 1 & 1 \\
\hline Diacanthum filapicatum (Gocht) Stover \& Evitt 1978 & 1 & & & 1 & & & 1 \\
\hline Ellipsoidictyum cinctum Klement 1960 & 2 & & 1 & 4 & & & \\
\hline Escharisphaeridia pocockii (Sarjeant) Erkmen \& Sarjeant 1980 & 11 & 14 & 2 & 17 & & 3 & 1 \\
\hline Escharisphaeridia sp. of Riding et al. 1985 & 4 & & & 6 & & 1 & 2 \\
\hline Fromea tornatilis (Drugg) Lentin \& Williams 1981 & & & & & 2 & 2 & 3 \\
\hline Gonyaulacysta jurassica (Deflandre) Norris \& Sarjeant 1965 & & & & & & 2 & 3 \\
\hline Gonyaulacysta jurassica var. longicornis (Deflandre) Gitmez 1970 & & & & & & & 1 \\
\hline Hystrichogonyaulax cladophora (Deflandre) Stover \& Evitt 1978 & & & & & & & 3 \\
\hline Jansonia jurassica Pocock 1972 & & & & & & & 2 \\
\hline Leiofusa jurassica Cookson \& Eisenack 1958 & 1 & 1 & & & & & \\
\hline Kylindrocysta spinosa Fenton et al. 1980 & 2 & 1 & & 3 & & & \\
\hline Lithodinia jurassica Eisenack 1935 & & & & & 3 & 3 & 4 \\
\hline Meiourogonyaulax cf. callomonii Sarjeant 1972 & & & & & & 1 & 1 \\
\hline Meiourogonyaulax deflandrei Sarjeant 1968 & & & & & & 2 & \\
\hline Meiourogonyaulax spongiosa sp. nov. & & & & & & 23 & 67 \\
\hline Meiourogonyaulax valensii Sarjeant 1966 & & & & & & 2 & 9 \\
\hline Micrhystridium spp. & 2 & 4 & 2 & 5 & 3 & 4 & 1 \\
\hline Nannoceratopsis pellucida Deflandre 1938 & & 5 & & 3 & 3 & 11 & 12 \\
\hline Paragonyaulacysta calloviense Johnson \& Hills 1973 & & & & & & 2 & 2 \\
\hline Pareodinia alaskensis Wiggins 1975 & 3 & & & 2 & & & \\
\hline Pareodinia ceratophora Deflandre 1947 & 2 & 3 & & & 4 & & 1 \\
\hline Pareodinia brachythelis Fensome 1979 & & & & & 2 & & \\
\hline Pluriarvalium osmingtonense Sarjeant 1962 & 9 & 12 & & & 36 & 3 & 2 \\
\hline Parvocysta bjaerkei sp. nov. & 3 & 5 & & & 4 & 3 & \\
\hline Pterospermopsis spp. & 1 & & 1 & 3 & & & \\
\hline Scriniocassis dictyotus (Cookson \& Eisenack) Beju 1971 & & & & & & & 2 \\
\hline Scriniocassis pirum (Gitmez) Davies 1983 & 1 & & & 1 & & & \\
\hline Sentusidinium baculatum (Dodekova) Sarjeant \& Stover 1978 & & & & & & & \\
\hline Sentusidinium pelionense Fensome 1979 & 11 & 15 & & 18 & & & \\
\hline Sentusidinium pilosum (Ehrenberg) Sarjeant \& Stover 1978 & & & & & & & 1 \\
\hline Sentusidinium sp. B of Fensome 1979 & & & & & & 1 & \\
\hline Sirmodinium grossii Alberti 1961 & 22 & 32 & & 21 & 5 & 3 & 35 \\
\hline Susadinium? sp. A & & & & & & & 1 \\
\hline Tubotuberella eisenackii (Deflandre) Stover \& Evitt 1978 & & & & & & 2 & 2 \\
\hline Tubotuberella cf. whatleyi (Sarjeant) Stover \& Evitt 1978 & & & & & & & 1 \\
\hline Valensiella ampulla Gocht 1970 & & & & & & 3 & 1 \\
\hline Valensiella ovula (Deflandre) Eisenack 1963 & & & 2 & & 3 & 10 & 13 \\
\hline Veryhachium spp. & 2 & & & & & 1 & 1 \\
\hline Bisaccates & 89 & 77 & 5 & 76 & 21 & 90 & 20 \\
\hline Other pollen + spores & 13 & 21 & 42 & 32 & 68 & 34 & 18 \\
\hline
\end{tabular}

those of Riley \& Fenton (1982) and Woollam \& Riding (1983), who correlated the boundaries of their dinoflagellate cyst zones with the boreal ammonite zonations. Riley \& Fenton (1982) div- ided the Callovian and Oxfordian of north-west Europe into four zones and five subzones, while Woollam \& Riding (1983) proposed six zones and nine subzones for the Bathonian, Callovian, and 
Oxfordian Stages. It is clear that none of the existing zonation schemes can be used precisely within the Barents Sea Region, but some rough correlations with the British Jurassic are discussed here.

\section{The Late Bathonian assemblages}

The dinoflagellate cyst assemblages recorded from the Cape Flora samples CF-1 and CF-2, and the Windy Gully samples WG-1 and WG-2, can be correlated with the Ctenidodinium combaziiCtenidodinium sellwoodii $(\mathrm{Ccb} / \mathrm{Cs})$ Zone of Woollam \& Riding (1983). The age of this zone is Bathonian to early Callovian. The presence of Sirmiodinium grossii in the samples listed above indicates that the recorded assemblages can be placed within the $\mathrm{Ccb} / \mathrm{Cs}$ subzone $\mathrm{B}$, which is dated as Late Bathonian (middle Discus ammonite zone) to early Callovian (middle Macrocephalus zone). This correlation of the beds at $130-135 \mathrm{~m}$ a.s.l, at Cape Flora, and $99-151 \mathrm{~m}$ a.s.l. at Windy Gully, is in agreement with the earlier proposed age based on the macrofauna (Table 1).

Taxa known both from the Late Bathonian dinoflagellate cyst assemblages from Franz Josef Land and from the $\mathrm{Ccb} / \mathrm{Cs}$ Zone of the British Jurassic include Diacanthum filapicatum, Ctenidodinium continuum, C. ornatum, Chytroeisphaeridia chytroeides, Escharisphaeridia spp., Kylindrocysta spinosa, Nannoceratopsis pellucida, Pareodinia ceratophora, Sentusidinium spp., and representatives of the EllipsoidictyumValensiella complex. However, the key species Cteniododinium combazii and Cteniododinium sellwoodii, which dominate within the $\mathrm{Ccb} / \mathrm{Cs}$ Zone in England. have so far not been recorded from Franz Josef Land. Data from Kong Karls Land (Bjærke 1977; Smelror 1988) and Spitsbergen (Bjærke 1980) seem to indicate that these species are very rare within the Barents Sea Region.

\section{The early Upper Callovian assemblages}

The samples CF-3 and CF-U from Cape Flora contain rich and diverse distinct Callovian dinoflagellate cyst assemblages. but based on the palynological data alone it is difficult to give more precise correlations. Several of the species recorded are well-known from the Ctenidodinium ornatum-Ctenidodinium continuum ( $\mathrm{Co} / \mathrm{Ccn})$ Zone and the Wanaea thysanota (Wt) Zone of Woollam \& Riding (1983), but the key species used to define the boundaries of these zones have not been observed from Franz Josef Land. As seen in the $\mathrm{Co} / \mathrm{Ccn}$ and $\mathrm{Wt}$ zones of the British Jurassic, the Callovian assemblages from Franz Josef Land are more diverse than those in the $\mathrm{Ccb} / \mathrm{Cs}$ zone below. In addition to Ctenidodinium ornatum and $C$. continuum, important taxa known from this interval both in England and Franz Josef Land include Hystrichogonyaulax cladophora, Gonyaulacysta jurassica, Lithodinia jurassica, and Tubotuberella spp.

The macrofauna suggests that the deposits from 150-172 m a.s.l. at Cape Flora are of early Upper Callovian age. The presence of Ambonosphaera calloviana suggests that the samples CF-3 $(168 \mathrm{~m})$ and CF-U (erratic) are of pre-Lamberti ammonite Zone age (according to the range reported by Berger (1986) for this species). This assumption is further supported by the absence of Acanthaulax senta, a species known from the Athleta Zone to the Densiplicatum Zone of the British Jurassic, and which is known to be abundant in Svalbard (Bjærke 1980; Smelror 1988). Thus, the samples CF-3 and CF-U from Cape Flora can probably be correlated with the Wanaea thysanota subzone A of Woollam \& Riding (1983), i.e. the Athleta ammonite zone.

\section{Comparisons with Bathonian- Callovian microfloras from Svalbard}

In Svalbard, marine microplankton assemblages comparable with the Bathonian and Callovian assemblages from Franz Josef Land have been reported from Kong Karls Land (Bjærke 1977; Thusu 1978; Smelror 1988) and from central Spitsbergen (Bjærke 1980).

In Kong Karls Land Bjærke (1977) recognized 'Association' D of Callovian age within the lower part of the Retziusfjellet Member of the Janusfjellet Formation. Characteristic species of Bjærke's 'Association' D also recorded from Franz Josef Land include: Tubotuberella eisenackii, Nannoceratopsis pellucida, Sirmiodinium grossii, Fromea tornatilis, Hystrichogonyaulax cladophora, Gonyaulacysta jurassica, Chytroeisphaeridia chytroeides, and Pareodinia ceratophora.

In his stratigraphic paper on Aptian to Toarcian dinoflagellate cysts from Arctic Norway. Thusu (1978) listed several species recognized within the Franz Josef Land assemblages. However, only two samples from Upper Bathonian-Callovian 
deposits of the Retziusfjellet Member were included in his study. A more detailed palynological study of the Middle Jurassic of Kong Karls Land was carried out by Smelror (1988) who outlined the distribution of 79 dinoflagellate cyst and acritarch taxa through the Hårfagrehaugen section on Kongsøya. Excluding Kylindrocysta spinosa and Leiofusa jurassica, all of the species recognized from the Upper Bathonian of Franz Josef Land were also recorded from contemporaneous strata in Kong Karls Land. As observed within the Upper Bathonian samples from Franz Josef Land, Sentusidinium spp., Escharisphaeridia spp., and Sirmiodinium grossii are the most common taxa within the Upper Bathonian to lowermost Callovian part of the Retziusfjellet Member on Kongsøya, Kong Karls Land.

Several of the species recorded from the early Upper Callovian assemblages from Franz Josef Land are also present within the Callovian strata of Kong Karls Land. Most of these species are forms occurring below and/or above the early Upper Callovian interval on Kongsøya (Smelror 1988). Species exclusively known from the Callovian of both areas are Ambonosphaera calloviana, Paragonyaulacysta calloviense, Hystrichogonyaulax cladophora, Tubotuberella eisenackii, and Valensiella ovula. The three latter species are known from pre-Callovian strata elsewhere in northwest Europe.

The frequency distribution of the various dinoflagellate cyst taxa does not show directly equivalent patterns within the time-equivalent assemblages from Franz Josef Land and Kong Karls Land, although there are some similarities. Most prominent taxa within the Callovian Franz Josef Land assemblages are Chlamydophorella spp., Sentusidinium spp., Escharisphaeridia spp., Pareodinia spp., and Sirmiodinium grossi. However, the genera Meiourogonyaulax, Lithodina, and Valensiella, which are most common within the Franz Josef Land assemblages, are represented by relatively fewer specimens within the early Upper Callovian microfloras recorded from Kong Karls Land.

In central Spitsbergen, Bjærke (1980) recognized three assemblage zones within the Agardhfjellet Member of the Janusfjellet Formation. His Zone 1 was characterized by Nannoceratopsis pellucida, Tubotuberella eisenackii, Gonyaulacysta jurassica var. longicornis, and several species of the genera Pareodinia, Ellip- soidictyum, Pluriarvalium, and Ctenidodinium. The Assemblage Zone 1, which was recognized within the lower few metres at Knorringfjellet and Festningen, was regarded as uppermost Bathonian or Lower Callovian by Bjærke (1980). This author further defined an Assemblage Zone 2 characterized by Acanthaulax senta, Stephanelytron redcliffense, Lithodinia jurassica, Tubotuberella dangeardii, and Wanaea sp. Zone 2, which covers a $20-40 \mathrm{~m}$ thick interval immediately above Zone 1, was regarded as Middle or Upper Callovian age.

Bjærke (1980) suggested that the Assemblage Zone 1 of the Agardhfjellet Member in central Spitsbergen may be correlated with his 'Association D' defined in Kong Karls Land. Several of the species listed from Zone 1 of the Agardhfjellet Member by Bjærke (1980) are classified within open nomenclature, and it is not possible to give detailed comparisons. None of the species show equivalent restricted occurrence on both Spitsbergen and in Franz Josef Land.

The presence of Acanthaulax senta within Zone 2 of the Agardhfjellet Member indicates that these assemblages are slightly younger than the early Upper Callovian assemblages recorded from Franz Josef Land. Acanthaulax senta is known to have its earliest occurrence within the Late Callovian Lamberti zone within the English Jurassic (Woollam \& Riding 1983), although it may first appear within the underlying Athleta zone in East Greenland (Piasecki 1980; Poulsen 1985). Several of the species known from the Upper Bathonian and early Upper Callovian assemblages of Franz Josef Land and from Zone 1 of the Agardhfjellet Member, also occur within Zone 2 of the Agardhfjellet Member, and are thus of limited use in correlations. Additional data are needed to give more detailed comparisons.

\section{Systematic palynology}

\section{Class Dinophyceae Fritsch 1929 Order Peridiniales Haeckel 1894}

Genus Parvocysta Bjærke 1980

Type species: Parvocysta bullula Bjærke 1980

Parvocysta bjaerkei sp. nov. Figs. 4G, 8C \& D, Text-fig. 9 (see p. 237)

Description.- Dinoflagellate cysts basically subpentagonal in outline, with a more or less 

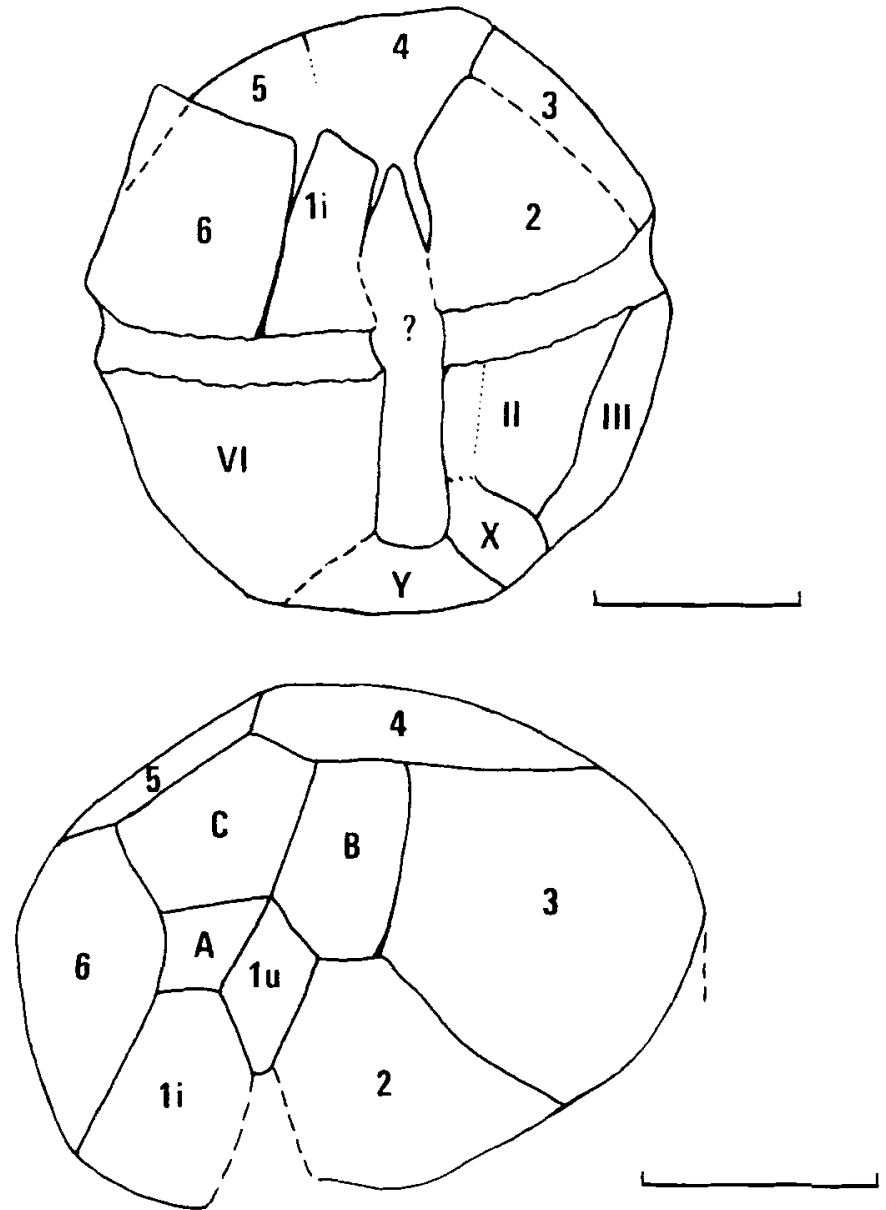

Fig. 3. Meiourogonyaulax spongiosa sp. nov. (scale bar $=$ $10 \mu \mathrm{m}$ ). Schematic line drawings labelled in the terms of the Taylor-Evitt notation system (sce Evitt 1985).

Fig. 4. Upper Bathonian and early Upper Callovian dinoflagellate cysts and acritarchs from Franz Josef Land.

A-C: Ambonosphaera calloviana Fensome 1979. A \& B: CF-U. F57/1. PA4386. Length $32 \mu \mathrm{m}$. C: CF-3, SEM CF-3 (1). Length $34 \mu \mathrm{m}$.

D \& E: Caddasphaera halosa (Filatoff) Fenton et al. 1980. D: WG-2 (B). A47/1. PA4387. Total width 60 $\mu \mathrm{m}$. E: SEM CF-3 (I). Width central body $28 \mu \mathrm{m}$.

F: Escharisphaeridia pocockii (Sarjeant) Erkmen \& Sarjeant 1980. CF-1, M52/4. PA4392. Width $50 \mu \mathrm{m}$.

G: Parvocysta bjaerkei sp. nov. SEM CF-3 (11). Width $45 \mu \mathrm{m}$.

H: Micrhystridium sp. SEM CF-3 (1). Width central body $30 \mu \mathrm{m}$.

I. Sirmiodinium grossii Alberti 1961. CF-U. F57/1. PA4386. Width $54 \mu \mathrm{m}$.

J: Nannoceratopsis pellucida Deflandre 1938. SEM CF-3 (1). Length $65 \mu \mathrm{m}$

K: Gonyaulacysta jurassica (Deflandre) Norris \& Sarjeant 1965. SEM CF-3 (I). Length $55 \mu \mathrm{m}$.

L: cf. Tubotuberella eisenackii (Deflandre) Stover \& Evitt 1978. SEM CF-3 (1). Length $60 \mu \mathrm{m}$. 

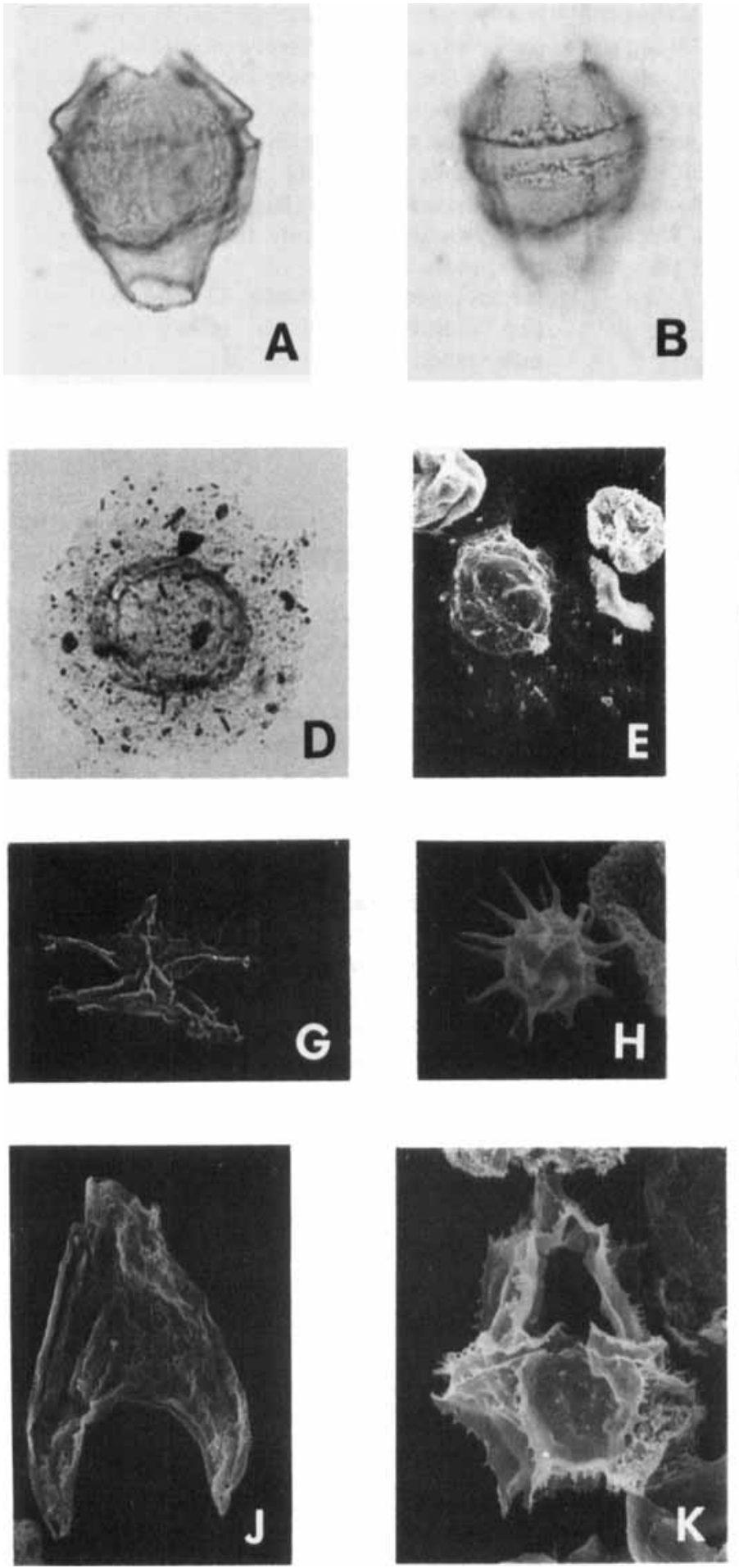
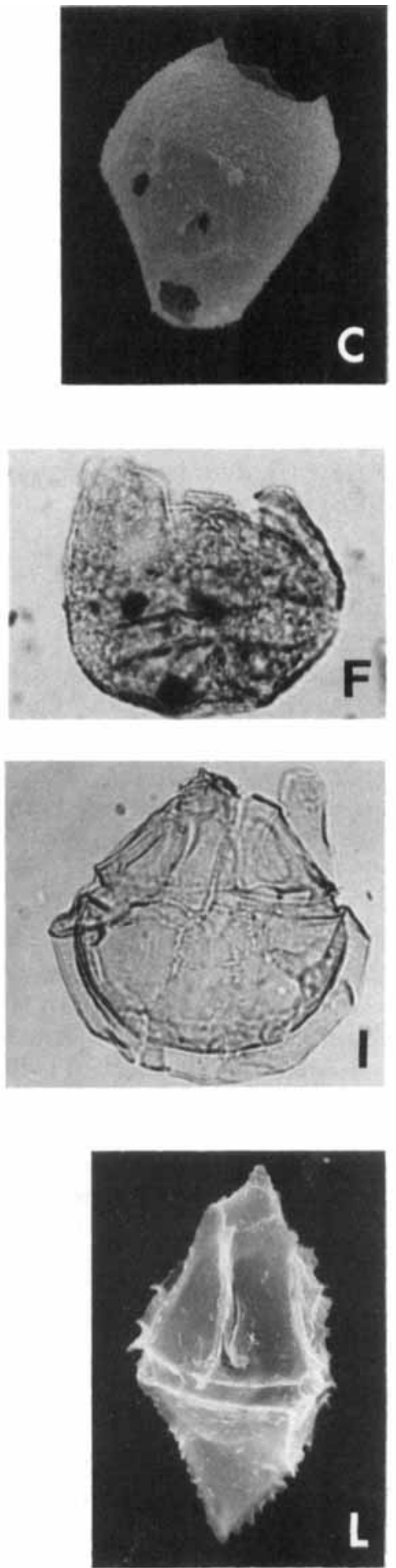
narrow paracingular region. A prominent apical horn and two precingular and two postcingular horn-like processes in lateral positions are present. Each of the lateral horns has a main branch and 3 to 5 fingerlike branches, sometimes with bifurcate distal tips. The cyst wall is single layered, smooth, sometimes with scattered short spines in the apical and antapical areas. The archeopyle appears to be intercalary, but the exact outline is not known.

Holotype. - SEM CF-3 (II), Figure 4G.

Dimensions. - Length including apical horn 38$54 \mu \mathrm{m}$. length of lateral processes $13-32 \mu \mathrm{m}$ (15 specimens measured).

Derivation name. - Named in honour of $\mathrm{T}$. Bjærke.

Type stratum and locality. - Early Upper Callovian strata, $168 \mathrm{~m}$ a.s.l. Cape Flora. Northbrook Island.

Occurrence. - Northbrook Island. Cape Flora. samples CF-2 and CF-3. Windy Gully, samples WG-1 and WG-2

Remarks. - Paruocysta bjaerkei sp. nov. was first described under open nomenclature as Parvocysta sp. B from the Toarcian of Spitsbergen by Bjærke (1980). Earlier. Bjærke (1977) recorded this species as Sp. Indet. (Pl. 10, Fig. 5) in his 'Association' D of Callovian age from Kong Karls Land. According to Haq et al. (1987. Fig.), representatives of the Parvocysta-complex became extinct within the Aalenian, while Woollam \& Riding (1983) regard the Early Bajocian as the stratigraphic top of these species. However, Smelror (1988) reported Parvocysta bjaerkei sp. nov. in both Toarcian deposits and strata ranging from Late Bathonian to Early Oxfordian in Kong Karls Land. The consistent distribution of this species throughout the Early and Middle Callovian deposits on Kongsøya (Kong Karls Land) suggests that reworking is unlikely. In addition, this species also occurs in Lower Callovian dinoflagellate cyst assemblages from eastern England and within the Callovian offshore mid-Norway (pers. observation).

Genus Meiourogonyaulax Sarjeant in Davey et al. 1966

Type species: Meiourogonyaulax valensii Sarjeant in Davey et al. 1966

Meiourogonyaulax spongiosa sp. nov. Figs. 5A-F, Text-fig. 3

Description.- Dinoflagellate cysts subspherical in outline. Autophragm is thick, spongy. The ornamentation appears irregular and variously developed, sometimes as a low reticulum or as more or less fossulate or even foveolate. A gonyaulacoid paratabulation is indicated by parasutural lines ranging from roughened to irregularly punctatoreticulate. The archeopyle appears to be composed of four apical paraplates, and is probably of type (4A).

There are six precingular paraplates. The number of paracingular plates are not known. The parasulcus is expressed as a relatively deep and broad sinerous depression. The parasulcal tabulation pattern is not known. Including the Iu, which rarely is clearly expressed, six postcingular paraplates are present. A posterior intercalary

Fig. 5. Heiourogonialax spongiosa sp. now. Early L'pper Callovian. Franz Josef Land.

A-D \& G: SEM CF-3 (I). A: Width $40 \mu \mathrm{m}$. B: Width $45 \mu \mathrm{m}$. C: Length 54 !m. D: Length $48 \mu \mathrm{m}$. G: Width $40 \mu \mathrm{m}$.

E: CF-L. N56/1. PA 4386 . Width 38 !nm

F: CF-L X53 1. PA1386. Width $32 \mathrm{um}$. 

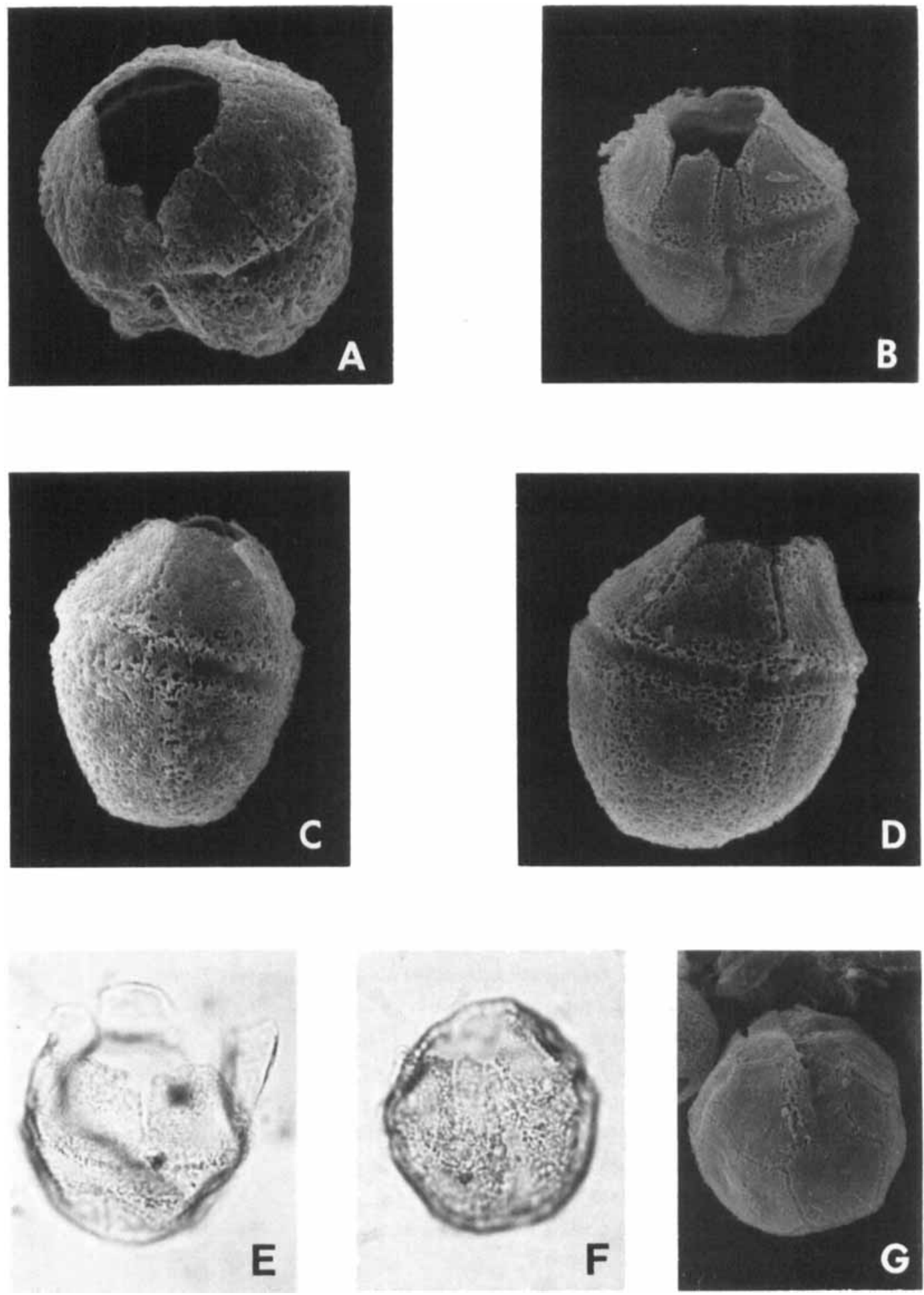
paraplate $(\mathrm{X} / \mathrm{lpV})$ is present on the left side of the sulcus. The antapical paraplate is 6 -sided and contacts VI (5"')') (i.e. the pattern is sexiform).

Holotype. - SEM CF-3(I), Figure 5B.

Dimensions. - Length (excluding apical paraplates) $35-52 \mu \mathrm{m}$, width $30-49 \mu \mathrm{m}$ ( 20 specimens).

Derivation of name. - 'Spongiosa', referring to the spongy autophragm.

Type stratum and locality. - Early Upper Callovian strata, $168 \mathrm{~m}$ a.s.l., Cape Flora, Northbrook Island.

Occurrence. - Northbrook Island, Cape Flora, sample CF-3 (168 m a.s.l.) and CF-U (erratic). Early Upper Callovian.

Remarks. - Meiourogonyaulax spongiosa sp. nov. seems comparable with Meiourogonyaulax reticulata Dodekova 1975. However, the Callovian specimens from Franz Josef Land differ from the Bulgarian Upper Bathonian specimens described by Dodekova (1975) in lacking well-developed reticulum. Specimens which most probably are conspecific with Meiourogonyaulax spongiosa sp. nov. have also been observed in Early Callovian dinoflagellate cyst assemblages from eastern England by the present author.

Genus Susadinium Dörhöfer \& Davies 1980

Type species: Susadinium scrofoides Dörhöfer \& Davies 1980

Susadinium? sp. A. Fig. $6 \mathrm{H}$

Description.- Dinoflagellate cyst, elongated hour-glass shaped in outline, with a short apical horn and slightly concave antapical area. Autophragm generally smooth and with short spines aligned in generally ?parasutural rows and with well-developed denticles on the pre- and postcingular protuberances. Epicyst and hypocyst separated by a deeply constricted paracingular area. Archeopyle formed by one or more intercalary paraplates.

Dimensions. - Length $35 \mu \mathrm{m}$, width paracingular area $13 \mu \mathrm{m}$ ( 1 specimen measured).

Occurrence. - Northbrook Island, erratic Callovian sample CF-U. Early Upper Callovian.

Remarks.- Only one specimen has been observed. This differs from other species of the genus Susadinium in having a very deeply constricted paracingular region, and having well-

Fig. 6. Upper Bathonian and early Upper Callovian dinoflagellate cysts and acritarchs from Franz Joscf Land.
A: Paragonyaulacysta calloviense Johnson \& Hills 1973. SEM CF-U (C). Length $50 \mu \mathrm{m}$.
B \& D: Ctenidodinium sp. SEM CF-3 (II). B: Width 96 um. D: Width $90 \mu \mathrm{m}$.
C: cf. Chlamydophorella sp. A of Davien 1983. SEM CF-3 (I). Width 34 um.
E: Meiourogonyaulax sp. SEM CF-3 (1). Length 58 !um.
F: Fromea tornatilis (Drugg) Lentin \& Williams 1981. CF-2. V58/4. PA4389. Length 60 $\mu \mathrm{m}$.
G: Meiourogonyaulax valensii Sarjeant 1966. CF-U. K46/1. PA4386. Length $66 \mu \mathrm{m}$.
H: Susudinium? sp. A. CF-U, K58/I. PA4386. Length $35 \mu \mathrm{m}$
1: Pareodinia alaskensis Wiggins 1975. CF-1, M52/4. PA4392. Length 70) $\mu \mathrm{m}$.
$\mathrm{J}$ : Cymatiosphaera sp. SEM CF-L (C). Width $40 \mu \mathrm{m}$.
K: Gonyaulacysta jurassica var. Longicornis (Deflandre) Gitmez 1970. CF-U. M52/3. PA4386. Length $95 \mu \mathrm{m}$. 

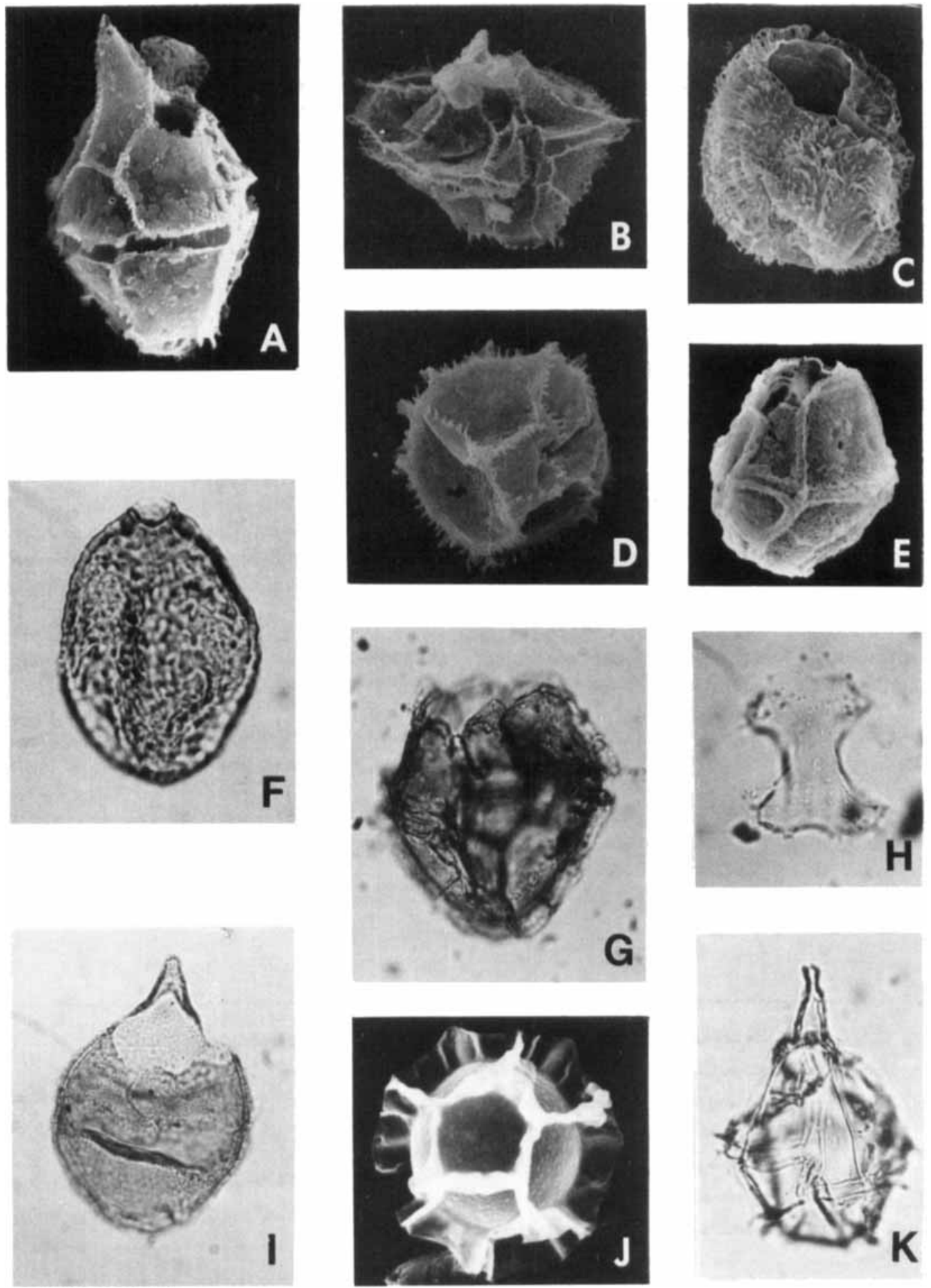
developed denticles on the pre- and postcingular protuberances.

This species is also recorded within the Lower Callovian Nordenskjoeldi ammonite zone on Jameson Land, East Greenland (pers. observations).

\section{Algae Incertae Sedis \\ Group Acritarcha Evitt 1963 \\ Genus Baltisphaeridium (Eisenack) Eisen- ack 1969}

Type species: Baltisphaeridium longispinosum (Eisenack) Eisenack 1959

\section{?Baltisphaeridium sp. A. Fig. 8B}

Description. - The vesicle is spherical in outline, hollow and thin-walled (less than $1 \mu \mathrm{m}$ ). The wall appears to consist of two layers, of which only the outer layer forms the processes. The processes (20-30 in number) are homomorphic acuminate. and are shorter than the vesicle diameter. Both vesicle and processes are smooth. The excystment structure is circular (cyclopyle) and the operculum apparently consists of 3 or 4 pieces.

Dimensions. - Diameter (excluding processes) $9 \mu \mathrm{m}$ ( 1 specimen measured).

Occurrence. - Northbrook Island, Cape Flora, sample CF-3 (Upper Callovian).
Remarks. - This species is here questionably placed in the genus Baltisphaeridium since there appears to be no solid plug at the base of the processes, separating the process interiors from the vesicle cavity. ?Baltisphaeridium sp. A seems comparable with Micrhystridium. However, representatives of the latter genus usually have epityche or median splitting excystment apertures.

\section{Genus Micrhystridium (Deflandre) Downie} \& Sarjeant 1963

Type species: Micrhystridium inconspicuum Deflandre 1937

\section{Micrhystridium sp. A. Fig. 7F}

Description. - The vesicle is subspherical in outline, hollow, with more than 25 short, broad acuminate processes. The vesicle wall and processes bear granulate to blunt echinate, well spaced ornamentation. Excystment by splitting of vesicle wall.

Dimensions, - Overall diameter $12 \mu \mathrm{m}$ (1 specimen measured).

Occurrence. - Northbrook Island, Cape Flora, sample CF-3 (Upper Callovian).

Remarks. - This species appears somewhat similar to the specimen illustrated as Micrhystridium sp.

Fig. 7. Upper Bathonian and early Upper Callovian dinoflagellate cysts and acritarchs from Franz Josef Land.
A: Meiourogonyaulax ef. callomonii Sarjeant 1972. SEM CF-3 (III). Width $62 \mu \mathrm{m}$.
B: Meiourogonyaulax valensii Sarjeant 1966. SEM CF-3 (III). Length $65 \mu \mathrm{m}$.
C: Verhachium sp. SEM CF-3 (I). Width (excluding process) $18 \mu \mathrm{m}$.
D: Valensiella sp. SEM CF-3 (III). Width $40 \mu \mathrm{m}$.
E: Sirmiodinium grossii Alberti 1961. SEM CF-3 (III). Width $60 \mu \mathrm{m}$.
F: Michystridium sp. A. SEM CF-3 (III). Width $12 \mu \mathrm{m}$. 

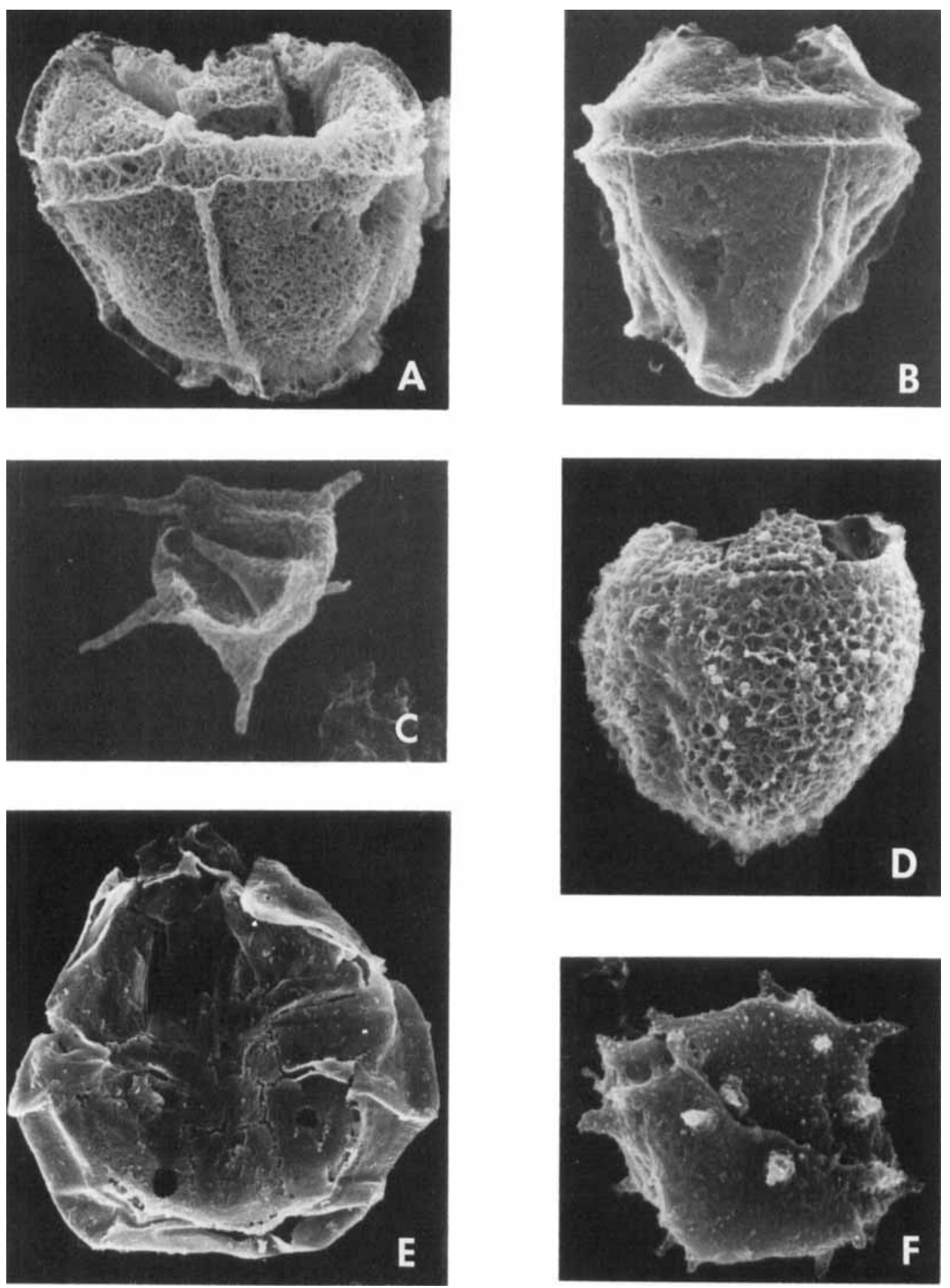

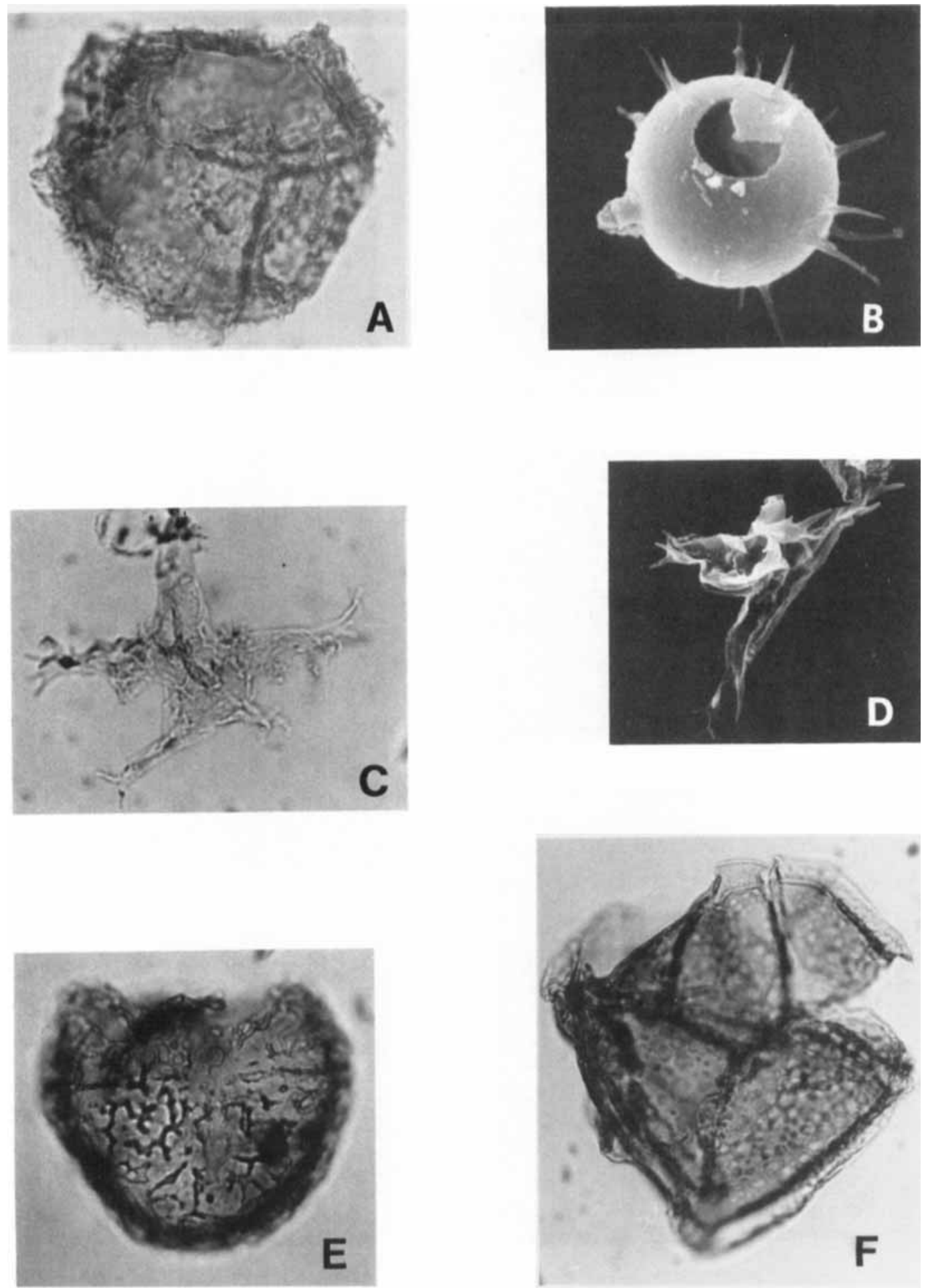


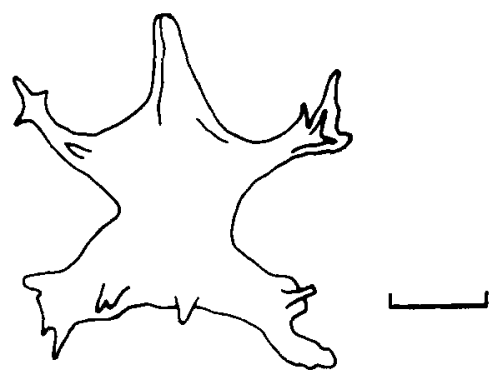

Fig. 9. Parvocysta bjaerkei sp. nov. (scale bar $=10 \mu \mathrm{m}$ ). Schematic line drawing (from Bjærke 1980).

from Toarcian deposits in NW Scania, Sweden, by Guy-Ohlson (1986, Pl. 18, Fig. 2). However, Micrhystridium sp. A from Franz Josef Land has relatively shorter processes and is less densely ornamented.

Acknowledgements. - The author would like to thank Dr. J. B. Riding (British Geological Survey) for reading an initial draft of the manuscript and offering helpful suggestions.

The assistance from $T$. Boassen (IKU) with the SEM and $T$. Aas (IKU) with the illustrations is also gratefully acknowledged.

\section{References}

Arkell, W, J. 1956: Jurassic geology of the world. Oliver \& Boyd, Edinburgh. 824 pp.

Barss, M. S. \& Williams, G. L. 1973: Palynology and Nannofossil processing tcchniques. Geol. Surv. Canada. Paper 73. 26. $22 \mathrm{pp}$.

Berger. J. P. 1986: Dinoflagellates of the Callovian Oxfordian boundary of the 'Liesberg-Dorf' quarry (Berner Jura, Switzerland). Neues Jb. Geol. Paläont. Abh. 172, 331-355.
Bjærke, T. 1977: Mesozoic palynology of Svalbard I1. Palynomorphs from the Mesozoic sequence of Kong Karls Land. Norsk Polarinst. Årbok 1976, 83-120.

Bjærke, T. 1980: Mesozoic palynology of Svalbard V. Dinoflagellates from the Agardhfjellet Member (Middle and Upper Jurassic) in Spitsbergen. Norsk Polarinst. Skr. 172. 145-167.

Davies, E. H. 1983: The dinoflagellate Oppel-zonation of the Jurassic-Lower Cretaceous sequence in the Sverdrup Basin, Arctic Canada. Geol. Surv. Canada, Bull. 359.59 pp.

Dodekova, L. 1975: New Upper Bathonian dinofiagellate cysts from north-eastern Bulgaria. Bulg. Acad. Sci. Palaeontol. Stratigr. Lithol. 2, 17-34.

Dibner, V. D. \& Shulgina, N. I. 1960: Results of stratigraphic investigation of marine Middle and Upper Jurassic deposits of Franz Josef Land. Trudy nauchno-issled Inst. Geol. Arkt. $114,65-77$.

Evitt, W. R. 1985: Sporopollenin dinoflagellate cysts. Their morphology and interpretation. Am. Assoc. Strat. Palynol. Found. $333 \mathrm{pp}$.

Guy-Ohlson. D. 1986: Jurassic palynology of the Vilhelmsfalt Bore no. 1, Scania. Sweden: Toarcim-Aalenian. Swedish Museum of Nat. Hist., Stockholm. 127 pp.

Haq, B. U., Hardenbol, J. \& Vail, P. R. 1987: Chronology of fluctuating sea levels since the Triassic. Science 35, 11561167.

Herngreen, G. F. W. \& De Bocr, K. F. 1978: Dinoflagellate zonations of Upper Dogger and ?lowermost Malm in the Netherlands. Palinologia Spec. 1, 283-291.

Horn, G. 1932: Some geological results of the Norwegian Expedition to Franz Joseph Land. Norsk Geol. Tidsskr. 11, $482-489$.

Johnson, C. D. \& Hills, L. V. 1973: Microplankton zones of the Savik Formation (Jurassic), Axel Heiberg and Ellesmere Islands, District of Franklin. Bull. Can. Petrol. Geol. 21.178218.

Nansen, F. 1900; Geological sketch of Cape Flora and its neighbourhood. Pp. 1-32 in Nansen. F. (cd.): The Norwegian North Polar Expedition 1893-96. Scientific resuls $1 / 1$ (1).

Newton, E. T. \& Teall, J. J. H. 1897: Notes on a collection of rocks and fossils from Franz Joseph Land made by the Jackson-Harmsworth Expedition during 1894-96. Quart. Journ. Geol. Soc. 53, 477-519.

Fig. 8. Upper Bathonian and early Upper Callovian dinoflagellate cysts and acritarchs from Franz Josef Land.

A: Meiourogonyaulax spongiosa sp. nov. CF-U, S27/0. PA4386. Width $42 \mu \mathrm{m}$.

B: Baltisphaeridium sp. A. SEM CF-3 (1I). Width $9 \mu$ m (excluding processes).

C: Parvacysta bjaerkei sp. nov. WG-2 (B), A47/1. PA4387. Width $38 \mu \mathrm{m}$.

D: Parvocysta bjaerkei sp. nov. SEM CF-3 (II). Width $40 \mu \mathrm{m}$.

E: Valensiella ooula (Deflandre) Eisenack 1963. CF-3, L49/0. PA4388. Width $58 \mu \mathrm{m}$.

F: Scriniocassis dictyotus (Cookson \& Eisenack) Beju 1971. CF-U, S49/0. PA4386. Width $69 \mu \mathrm{m}$. 
Piasecki. S. 1980: Middle to Late Jurassic dinoflagellate cyst stratigraphy from Milne Land and Jameson Land (East Greenland) correlated with ammonite stratigraphy. Unpubl. Cand. Scient. thesis, Lniversity of Copenhagen. $167 \mathrm{pp}$.

Pompeckj, J. F. 1900: The Jurassic Fauna of Cape Flora. Pp. 33-147 in Nansen. F, (ed.): The Norwegian North Polar Expedition 1893-96. Scientific results II (I).

Poulsen, N. E. 1985: Dinocyststratigrafi i den nedre del af Hareelv Formation (Øvre Jura), Jameson Land. Østgrønland. Dansk geol. Foren. Ảrskrift for 1984, 133-137.

Riley, L. A. \& Fenton, J. P. G. 1982: A dinocyst zonation for the Callovian to Middle Oxfordian succession (Jurassic) of Northwest Europe. Palynology 6, 193-202.

Sarjeant, W. A. S. 1979: Middle and Upper Jurassic dinoflagellate cysts: the world excluding North America. Contrib. Ser. Am. Assoc. Stratig. Palynol. 5b, 133-157.

Smelror. M. 1986: Jurassic and Lower Cretaceous palynomorph assemblages from Cape Flora. Franz Josef Land. Arctic U.S.S.R. Norsk Geol. Tidsskr. 66, 107-119.

Smelror, M. 1988: Bathonian to Early Oxfordian dinoflagellate cysts and acritarchs from Kong Karls Land, Svalbard. Rev. Palaeobot. Palynol. (in press).
Smith. D. G., Harland, W. B., Hughes. N. F. \& Picton, C. A G. 1976: The geology of Kong Karls Land, Svalbard. Geol. Mag. 113, 193-304.

Spath, L. F. 1932: Invertebrate Faunas of the Bathonian-Callovian deposits of Jameson Land (East Greenland). Meddel. om Gronland 87. $158 \mathrm{pp.}$

Spath, L. F. 1947: Additional observations on the invertebrates (chiefly ammonites) of the Jurassic and Cretaceous of East Greenland. Meddel, om Grønland 132. $70 \mathrm{pp}$.

Thusu, B. 1978: Aptian to Toarcian dinoflagellate cysts from Arctic Norway. Pp. 61-95 in Thusu, B. (ed.): Distribution of biostratigraphically diagnostic dinoflagellate cysts and microspores from the Northwest European continental shelf and adjacent areas. Continental Shelf Inst. Publ. 100.

Williams, G. L. 1977: Dinocysts: their classification, biostratigraphy and palaeoecology. Pp. 1231-1325 in Ramsay, A. T. S. (ed.): Oceanic micropalaeontology 2. Academipress, London.

Woollam. R. \& Riding. J. B. 1983: Dinoflagellate cyst zonation of the English Jurassic. Inst. Geol. Sci, London, Rep. 83/2, $1-42$. 